\title{
DECISION FACTORS BEHIND CHOOSING HIGHER EDUCATION INSTITUTIONS IN EUROPE
}

\author{
Viktorija Skvarciany $^{1}$, Inga Shina ${ }^{2}$, Fawad bin Sajjad ${ }^{3}$ \\ ${ }^{I}$ Vilnius Gediminas Technical University, Vilnius, Lithuania, viktorija.skvarciany@vgtu.lt \\ ${ }^{2}$ EKA University of Applied Sciences, Riga, Latvia, inga.shina@gmail.com \\ ${ }^{3}$ EKA University of Applied Sciences, Riga, Latvia, fawadbsb2015@gmail.com
}

\begin{abstract}
Research purpose. This article aims at distinguishing and weighting the educational factors that could have an impact on young people's choice to study in European higher education institutions (HEIs).

Design/Methodology/Approach. To achieve the aim, previous research and scientific literature were studied and experts from student society and the higher education sector, who deal with international students, were interviewed. The developed questionnaire was based on pairwise comparison procedure, and the obtained data were processed using the analytical hierarchy process (AHP) method.

Findings. The findings revealed that the following factors are the most critical for students who want to study at European HEIs: provision of programmes that are taught in English, the existence of scholarship opportunities, provision of different facilities in the campus, and accreditation of the study programme and university.

Originality/Value/Practical implications. The current study focuses on a topic that has been studied fragmentally, that is, on which factors are crucial for an international student to choose HEI in Europe. The current research contributes to the existing scientific literature by identifying and systemising educational factors influencing young people's choice to study in Europe. The obtained results could be useful for professionals who are responsible for strategic partnerships at European universities.
\end{abstract}

Keywords: Higher Education Institutions (HEI); International Students; Studying Abroad; Analytical Hierarchy Process (AHP).

JEL codes: J62; I23.

\section{Introduction}

In the era of globalisation, there are many opportunities for young people's international mobility in order to graduate abroad, especially in European countries. According to the European Commission (2018), the number of tertiary education students in the 28 EU countries in 2017 reached 19.8 million. A large number of students are those who came from abroad; hence, there are many scholars investigating this issue. There are scientists concentrating on the analysis of study programmes that are popular amongst international students (Clarke et al., 2020; Di Pietro, 2020). Other researchers focus on education abroad in terms of migration, that is, they investigate study abroad as an opportunity for students to change their residence (Naito \& Zhao, 2020). Moreover, scientists are interested in factors that motivate young people to study in a particular country, for instance, China (Gbollie \& Gong, 2020; Lee, 2020), India (Naito et al., 2020) and Taiwan (Lee, 2017). However, there the motivating factors for international students to study in Europe are studied fragmentally. Hence, the idea of the current research emerged because of the lack of studies analysing the factors influencing international students to choose European higher education institutions (HEIs) and the personal engagement of the authors with the study process within management programmes. Being actively involved in teaching and studying, the authors are interested in delivering relevant knowledge for HEIs, education consultants and governments to increase the number of international students. The current research aims at identifying the factors 
influencing international students' choice of HEIs in Europe.

Moreover, it is worth mentioning that several factors motivating study abroad are vast. Hence, in the current research, only educational factors are examined. Apart from that, there are several limitations to the study. The current is focused on 'third-country national' internationally mobile students. According to the Council Directive 2004/114/EC, 'third-country national' means any person who is not a citizen of the European Union (European Commission, 2004).

\section{Literature Review}

There are many materials on international students' education in European countries. Some countries have introduced research about international students' attraction and retention (Leiškalne et al., 2018) to solve labour market challenges in Europe. They look to the international students from developed countries as a possibility of tackling an ageing population problem, maintain the welfare system and attract a skilled workforce. However, there is not enough research about the factors influencing international students from third countries' choice of HEIs in Europe.

First, the authors reviewed the literature about consumer behaviour in order to identify the main factors of consumer choice and especially about variables affecting customer conduct. The literature review of consumer conduct or behaviour is various and broad as changes in the society, economics or financial matters and innovation in technology influence how consumers to act (Peighambari et al., 2016). There is a wide scope of variables that can influence purchaser conduct in various manners. These components are split by Hoyer et al. (2012) into four general classes:

- Situational

- Individual

- Social

- Cultural components.

Each factor is briefly described below (Hoyer et al., 2012; Patil \& Bakkappa, 2012):

- Situational factors affecting purchaser conduct may incorporate area, condition, timing and, considerably, climate conditions

- Personal/individual elements include taste inclinations, own money related conditions and related components or factors

- Social variables affect shopper's behaviour. The opinion pioneers, as a rule, promoting items and services

- Culture and utilisation or consumption have had an extraordinary relationship in the cuttingedge world.

They further contend that given this relationship and the way that the world economy is turning out to be progressively multifaceted, a comprehension of how culture impacts buyer conduct by advertisers will be pivotal, all the more with the goal that culture has extreme power in managing human behaviour. Spiers et al. (2014) noticed that purchaser conduct is affected and inspired by elements, for example, culture, character, way of life, pay, perspectives, helpers, emotions, information, ethnicity, family, values, accessible assets, sentiments, encounters and different gatherings. Culture, subculture and social class are known to have significant effects on individuals' conduct because they are ground-breaking drivers in the development of mentalities, convictions and qualities (Blythe, 2008). Table 1 presents the components that impact human conduct whilst settling on a choice on the selection of items or influencing customer conduct (Table 1). 
Table 1. Factors influencing humans' choice (Source: Authors' compilation)

\begin{tabular}{|c|c|c|c|}
\hline No. & Major factor & Subfactors & Description \\
\hline \multirow{3}{*}{1.} & \multirow{3}{*}{$\begin{array}{l}\text { Cultural } \\
\text { factors }\end{array}$} & Culture & $\begin{array}{l}\text { Variables allude to the arrangement of essential qualities, needs and } \\
\text { practices learned by an individual from a general public from the } \\
\text { family and other significant organisations. }\end{array}$ \\
\hline & & Subculture & $\begin{array}{l}\text { Each culture contains small subsocieties. Subculture incorporates } \\
\text { nationalities, religions, racial groups and geographic locations. }\end{array}$ \\
\hline & & Social class & $\begin{array}{l}\text { Individuals who share comparable qualities, interests and practices. } \\
\text { Social class can be dictated by a blend of occupation, salary and } \\
\text { instruction. }\end{array}$ \\
\hline \multirow{3}{*}{2.} & \multirow{3}{*}{ Social factors } & Groups & $\begin{array}{l}\text { Group alludes to at least two people who interact to achieve } \\
\text { individual or shared objectives. An individual's conduct is affected } \\
\text { by numerous little groups. These groups include family, } \\
\text { companions and neighbours. }\end{array}$ \\
\hline & & Family & $\begin{array}{l}\text { Individuals can unequivocally impact a purchaser's conduct. } \\
\text { Advertisers are keen on the influences of the spouse, partners and } \\
\text { kids on the acquisition of various items. }\end{array}$ \\
\hline & & $\begin{array}{l}\text { Roles and } \\
\text { status }\end{array}$ & $\begin{array}{l}\text { The individual's situation in each group can be characterised as far } \\
\text { as both role and status. } \\
\text { Every job conveys a status that is presented by society. }\end{array}$ \\
\hline \multirow[t]{3}{*}{3.} & \multirow{3}{*}{$\begin{array}{l}\text { Personal } \\
\text { factors }\end{array}$} & $\begin{array}{l}\text { Age and life } \\
\text { cycle stage }\end{array}$ & $\begin{array}{l}\text { Individuals change their purchase preferences over their lifetimes. } \\
\text { Advertisers characterise their markets as far as family life cycle } \\
\text { arrange and create fitting plans and items for each stage. }\end{array}$ \\
\hline & & Occupation & $\begin{array}{l}\text { An individual's occupation influences the purchase of goods and } \\
\text { services. }\end{array}$ \\
\hline & & $\begin{array}{l}\text { Economic } \\
\text { situation }\end{array}$ & $\begin{array}{l}\text { An individual's monetary circumstances influence their purchasing } \\
\text { decision. }\end{array}$ \\
\hline
\end{tabular}

Factors affecting consumer behaviour can be a combination of two or more factors. Also, each factors' impact is not the same. This indicates that each individual has his or her own major and minor factors that influence his or her behaviour and is subject to change. There are eight main factors that the authors consider for further analysis.

Second, the authors found factors influencing the choice of higher education institution. Several researchers before have examined the factors. Several case studies in different countries in different regions about factors influencing HE decision, for example, Iraq, United Arab Emirates, Latvia and Poland, have been conducted. The authors examined them and discovered the main factors.

Guibourg (2011) pointed out the financing cost to attend courses at the university as one of the top factors in choosing the location of the institution. The cost of living is also mentioned as one of the significant factors for consideration (María Cubillo et al., 2006) when choosing to study abroad.

International students nowadays use many resources to help them make decisions - the Internet, education consultants, exhibitions and government resources. However, they do not have enough knowledge about the quality of education offered by HEIs abroad. Most HEIs focus on the Internet as a primary source of information to establish a relationship with the potential student and to destroy cultural and geographical barriers between the host and home country of the student (Usunier \& Lee, 2009).

The study conducted to understand the selection process by students states a few factors in Table 2 . 
Table 2. Key factors that influence undergraduate selection practices in favour of higher education institutions (Source: Authors compilation based on the research work by Vevere \& Mons, 2020)

\begin{tabular}{|l|l|l|}
\hline No. & Context & Subfactors \\
\hline 1. & $\begin{array}{l}\text { Motivation for } \\
\text { studying }\end{array}$ & $\begin{array}{l}\text { a) Educational and personal development; } \\
\text { c) Eursuance of a selected career path } \\
\text { c) Individual's characteristics }\end{array}$ \\
\hline $\begin{array}{l}\text { Key factors in } \\
\text { decision making } \\
\text { for choosing a } \\
\text { study programme }\end{array}$ & $\begin{array}{l}\text { a) Reputation of the study programme } \\
\text { c) Ranking of the programme } \\
\text { d) Location: safety, recreational possibilities, cost of living and welcoming of } \\
\text { international students }\end{array}$ \\
\hline 3. & $\begin{array}{l}\text { Key factors in } \\
\text { decision making } \\
\text { for choosing a } \\
\text { university }\end{array}$ & $\begin{array}{l}\text { c) Employability rate } \\
\text { c) Updated technology-wise and availability of online class options } \\
\text { d) Whether the HEI offers placement options } \\
\text { e) High volume of face-to-face teaching hours }\end{array}$ \\
\hline
\end{tabular}

A paper written in Iraq with the aim to understand the perception of students whilst selecting a university revealed the main factors influencing the choice of HEIs (Budur et al., 2018):

- Quality of education

- IT services

- Atmosphere comprising of social activities

- Social facilities

- Reputation of the university

- Academic staff

- Scientific activities

- Internationality of the university

- Financial aid and scholarship.

The research to investigate the factors determining student destination choice of HE in the United Arab Emirates was conducted (Ahmad \& Hussain, 2017). The authors came up with several factors that are presented in Table 3.

Table 3. Factors determining student's choice of higher education (Source: Ahmad \& Hussain, 2017)

\begin{tabular}{|l|l|l|}
\hline No. & Factors & Subfactors \\
\hline 1. & $\begin{array}{l}\text { Learning } \\
\text { environment }\end{array}$ & $\begin{array}{l}\text { (a) Comfortable climate, (b) environment conducive to learning, (c) safety, (d) } \\
\text { multiculturality, (e) English speaking and (f) economic and political stability }\end{array}$ \\
\hline
\end{tabular}




\begin{tabular}{|c|c|c|}
\hline 2. & Cost & $\begin{array}{l}\text { (a) Cost of living, (b) tuition fee, (c) traveling costs, (d) visa approval time, (d) } \\
\text { degree duration and (e) part-time work possibilities }\end{array}$ \\
\hline 3. & $\begin{array}{l}\text { Institutional } \\
\text { reputation }\end{array}$ & $\begin{array}{l}\text { (a) Quality of education, (b) university reputation, (c) degree recognition, (d) } \\
\text { course diversity, (e) simplicity of admission, (f) facilities of institution, (g) } \\
\text { ranking of institution, (h) scholarship options and (i) employment prospects }\end{array}$ \\
\hline 4. & $\begin{array}{l}\text { Personal } \\
\text { Development }\end{array}$ & $\begin{array}{l}\text { (a) International exposure, (b) migration intention, (c) potential to improve } \\
\text { language skills, (d) international contacts and (e) career enhancement }\end{array}$ \\
\hline 5. & Recommendation & (a) Family, (b) friends, (c) teachers, (d) alumni, (e) agent and (f) media \\
\hline 6. & $\begin{array}{l}\text { Socio-cultural } \\
\text { proximity }\end{array}$ & $\begin{array}{l}\text { (a) Religious homogeneity, (b) proximity to home country, (c) friends, (d) } \\
\text { relatives, (e) cultural homogeneity and (f) halal food }\end{array}$ \\
\hline 7. & $\begin{array}{l}\text { Government } \\
\text { initiatives }\end{array}$ & $\begin{array}{l}\text { (a) Scholarship schemes, (b) government relations and (c) institutional } \\
\text { collaboration }\end{array}$ \\
\hline
\end{tabular}

In turn, Rika et al. (2016) focused on factors affecting the choice of HEIs by prospective students in Latvia (Table 4)

Table 4. Factors affecting choice of HEI (Source: authors' compilation based on the results of the study done by Rika et al. (2016))

\begin{tabular}{|l|l|l|}
\hline No. & Factors & Subfactors \\
\hline 1. & Culture & $\begin{array}{l}\text { (a) Religious affiliation, (b) Nationality, (c) Ethnic origin, (d) Embedded } \\
\text { societal norms, (e) Traditions and (f) Family culture }\end{array}$ \\
\hline 2. & Social & (a) Family members, (b) friends and (c) society at large \\
\hline 3. & Psychological & (a) Attitude and (b) Belief \\
\hline 4. & Organisational factors & $\begin{array}{l}\text { (a) Specific characteristics of HEI and (b) actions of educational } \\
\text { institutions themselves }\end{array}$ \\
\hline
\end{tabular}

A study titled 'Determinants of higher education choices and student satisfaction: the case of Poland' was conducted by Sojkin et al. Table 5 is a compilation of complex factors determining decisions about pursuing a university education.

Table 5. Factors determining decisions about pursuing a university education (Source: Sojkin et al. (2012))

\begin{tabular}{|l|l|l|}
\hline No. & Items & Determinants \\
\hline 1. & $\begin{array}{l}\text { Choice of pursuing higher } \\
\text { education }\end{array}$ & $\begin{array}{l}\text { (a) Student - the type of life, (b) professional advancement, (c) family } \\
\text { opinion and expectation, (d) family financial support and (e) increased } \\
\text { chances at a job }\end{array}$ \\
\hline
\end{tabular}




\begin{tabular}{|l|l|l|}
\hline 2. & Choice of university & $\begin{array}{l}\text { (a) Marketing efforts, (b) professional development, (c) university } \\
\text { tradition, (d) courses offered, (d) university reputation, (e) cost of studies } \\
\text { and (f) accessibility of financial aid }\end{array}$ \\
\hline
\end{tabular}

To understand why students want to study in Europe, the authors look at the HE system in Europe. As per Zahav and Friedman (2019), the Bologna Process and the following foundation of the European Higher Education Area have affected the manners by which advanced education in Europe works and the manners in which it is seen and identified within nations and areas outside Europe. European advanced education used to be known for its exceedingly differing national frameworks. At present, the Bologna Process describes the procedure that built up the European Higher Education Area (EHEA). This has led to an expansion in programmes in English, to universally conspicuous advanced education structures and too straightforward quality confirmation measures (European Commission, 2017). According to Trejos (2019), the EHEA framework guarantees that advanced education frameworks across Europe are right and that students, scientists and academics in Europe can study or work abroad more effectively. Qualifications across Europe are similar through the European Qualifications Framework (EQF).

As a next step, the authors describe EQF. European degrees are connected in a more extensive system of qualification of the EHEA. This is the system settled upon by 46 European nations and depicts what skills and competences you should have to do a graduation in a specific programme. The point of the structure of this system is to advance universal straightforwardness, acknowledgement and portability of European degrees (European Commission, 2017). According to the European Commission (s.a.), as a significant aspect of the EHEA, every nation taking an interest consented to:

- Present a three-cycle advanced education framework comprising of bachelor's, masters and doctoral study programmes

- Guarantee the shared acknowledgement of capabilities and learning periods abroad finished at different educational institutions

- Actualise an arrangement of value confirmation, to reinforce the quality and importance of learning and educating.

EHEA ought to be recognisable by its straightforwardness, by its practically identical degrees sorted out in a three-cycle structure, by its participation in quality affirmation and by its universal acknowledgement of degrees. This permits unlimited versatility to understudies, graduates and advanced education staff (European Commission, 2017).

The all-encompassing framework for qualifications of the EHEA gets its particular purposes from the goals communicated through the Bologna Process: international transparency, acknowledgement and movement. Worldwide acceptance of qualifications expands on openness. The general qualification framework gives a typical comprehension of the results as a contrast to a mere comparison of qualification (recognition). The all-encompassing qualification framework incredibly improves the value of qualification over the EHEA. The stakeholders of higher education in Europe contributed to the development of the overall qualification framework (European Commission, n.d.-b).

The authors emphasise that each nation in Europe has its instruction framework. Framework for qualifications of the EHEA depends on an intergovernmental understanding within the Bologna Process. The framework's point is to sort out national advanced education capabilities into an all-encompassing European-wide qualification structure. Conventional descriptors of the immediate learning results at each level have been characterised by a group of experts within the Bologna Process. These descriptors are applicable in every national setting.

\section{Methodology}

The authors selected a questionnaire as a research tool for achieving the research aim. After reviewing the literature and scientific research work performed by various authors, the authors came up with a 
compilation of the top 10 educational factors that influence consumer behaviour in general and matching factors that influence consumers in the choice for their HEI. They are listed as follows:

- Ranking of the university

- Reputation of the university

- Accreditation of the programme and university

- Facilities on campus (latest technology used for teaching, library, cafeteria, etc.)

- Educational qualification and work experience of teaching staff

- Accommodation facilities provided

- Scholarship opportunities

- Internship opportunities

- Programmes are taught in English

- Admission process is easy

The questionnaire is based on the pairwise comparison, and the results are obtained using an analytical hierarchy process (AHP) proposed by Wind and Saaty (1980). According to the method, experts compare alternatives $\left\{\theta_{1}, \ldots, \theta_{n}\right\}$ with each other by filling pairwise comparison matrices $A=\left(a_{i j}\right)_{n \times n}$, where $a_{i j}=\frac{\omega_{i}}{\omega_{j}}, \forall i, j=1,2, \ldots, n ; \omega_{n}(n=1,2, \ldots n)$ - priority vector; $a_{i j}=\frac{1}{a_{j i}}, \forall i, j=1,2, \ldots, n$.

After experts complete pairwise comparison of the factors, all the matrices are evaluated with regards to consistency. The matrix is consistent if there is such priority vector $\mathbf{w}=\left(\omega_{1}, \ldots, \omega_{n}\right)$ that $a_{i j}=$ $=\omega_{i} / \omega_{j}, \forall i, j$. For that issue, the consistency index (CI) is calculated (Saaty, 1993). To compute the $\mathrm{CI}$, an eigenvalue of the pairwise comparison matrix $\lambda_{\max }$ is calculated first: $\lambda_{\max }=\sum_{j=1}^{n} \frac{(\mathrm{A} \cdot v)_{j}}{n \cdot v_{j}}$, where A is the comparison matrices, $n$ is the number of rows in a matrix and $v_{j}$ is an eigenvalue of a matrix. Consistency requirement is fulfilled if $\lambda_{\max }$ is equal or close to $n$. After CI is computed, a consistency ratio (CR) should be calculated by dividing CR by random index, that is, fixed values for different $n$ (Thomas L. Saaty, 2012). If $C R \in[0 ; 0,2$ ), it means that the matrix is consistent (Аксёнов et al., 2014). In other words, for experts' consistent pairwise comparison matrices, the aggregated experts' assessment is calculated using geometric mean (Kostin, 2014; Wu, Chiang \& Lin, 2008). After the aggregated matrix is developed, the weights of factors $\omega_{j}$ are computed using the normalised geometric mean method (Franek \& Kresta, 2014).

\section{Empirical Findings}

The research on factors of individual clients' confidence in mobile banking took place in Latvia and Lithuania in April 2020. Seven experts from the two countries took part in the survey. Experts with an experience of working with international students were selected for the assessment of the distinguished educational factors. The characteristics of the experts who participated in the study are presented in Table 6.

Table 6. Characteristics of experts (Source: Designed by authors)

\begin{tabular}{|l|l|}
\hline Experts & Characteristics \\
\hline $\mathrm{E}_{1}$ & Vice-Rector for Science; Professor; PhD, 10 years \\
\hline $\mathrm{E}_{2}$ & Professor; PhD; 8 years \\
\hline $\mathrm{E}_{3}$ & Study Programme Director; $\mathrm{PhD} ; 8$ years \\
\hline $\mathrm{E}_{4}$ & Professor; PhD; 10 years \\
\hline
\end{tabular}




\begin{tabular}{|l|l|}
\hline$E_{5}$ & Professor, PhD; 15 years \\
\hline$E_{6}$ & Study Programme Director; MSc; 4 years \\
\hline $\mathrm{E}_{7}$ & Associate Professor; PhD; 10 years \\
\hline $\mathrm{E}_{8}$ & Assistant Professor; PhD Candidate; 5 years \\
\hline
\end{tabular}

The experts evaluated 10 educational factors by comparing them to each other. The experts' individual comparison matrices and consolidated matrix are presented in Appendix 1. The results of the weighting procedure are presented in Table 7.

Table 7. Weights given by experts to educational factors influencing students' choice to study at European HEI (Source: authors' calculations)

\begin{tabular}{|l|l|}
\hline Factor & Weight (place) \\
\hline Ranking of the university & $0.042(10)$ \\
\hline Reputation of the university & $0.054(9)$ \\
\hline Accreditation of the programme and university & $0.102(4)$ \\
\hline Facilities on campus (latest technology used for teaching, library, cafeteria, etc.) & $0.112(3)$ \\
\hline Educational qualification and work experience of teaching staff & $0.070(7)$ \\
\hline Accommodation facilities provided & $0.076(6)$ \\
\hline Scholarship opportunities & $0.162(2)$ \\
\hline Internship opportunities & $0.069(8)$ \\
\hline Programmes are taught in English & $0.238(1)$ \\
\hline Admission process is easy & $0.080(5)$ \\
\hline
\end{tabular}

Visualisation of the results is presented in Figure 1. Moreover, absolute errors are depicted in the figure.

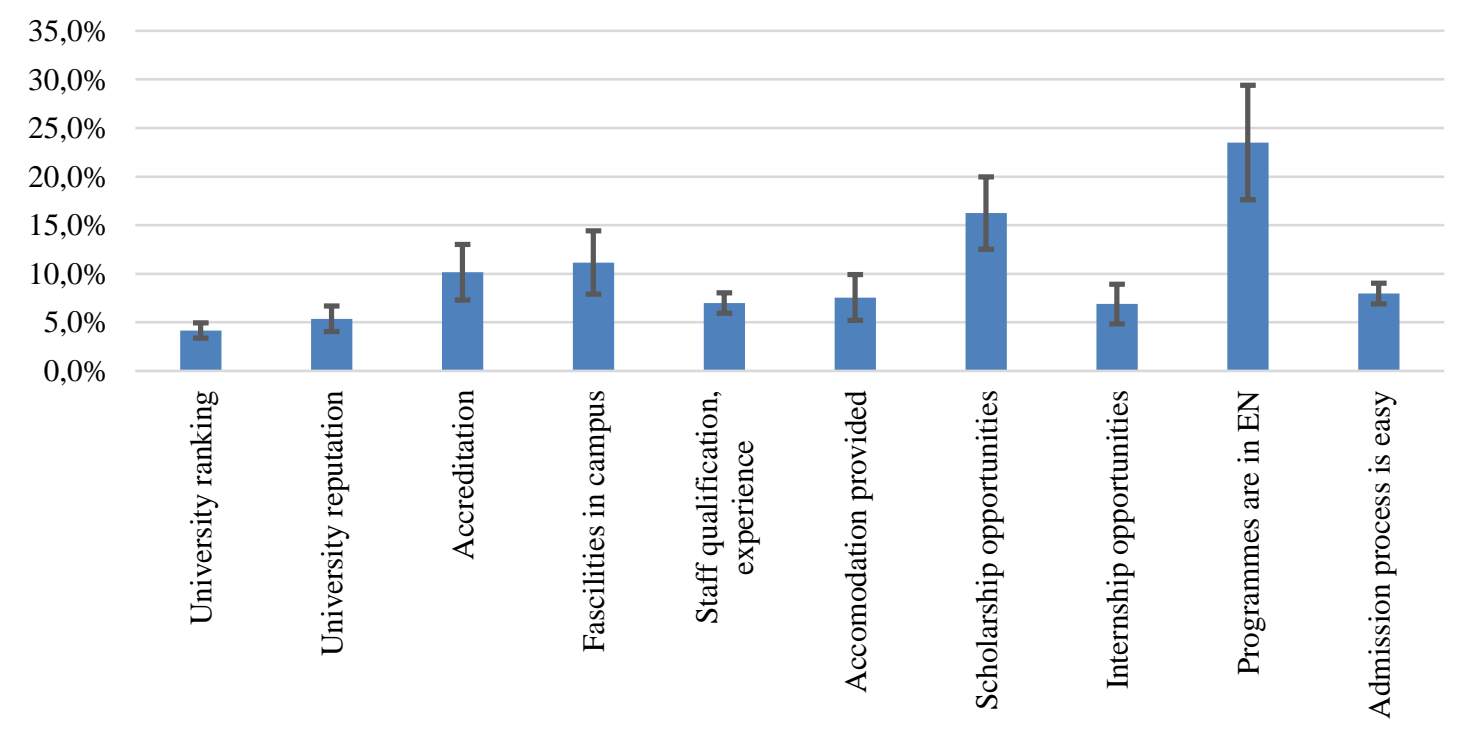

Fig. 1. Factors' weights obtained with AHP method and absolute errors (Source: Authors' calculations) 
The results presented in Figure 1 and Table 6 show that the most powerful and influencing educational factor is programmes taught in English. The weight of the factor is reasonably higher than other weights and reaches $23.8 \%$ with an absolute error of $\pm 5.9 \%$. In fact, the results are logical because English is considered to be an international language and almost all universities in Europe provide all or a part of their programmes in English. The second factor is scholarship opportunities for incoming students. The weight of the factor is $16.2 \%$ with an absolute error of $\pm 3.7 \%$. In fact, the opportunities to receive this kind of funding are one of the essential factors for students because most of the incoming students are from those third countries that considered as developing. This means that very few students can allow coming to Europe to study without any financial support. Facilities of the campus gained a third place in the ranking, and the weight of the factor is $11.2 \%$ and the absolute error is $\pm 3.3 \%$. It is quite evident that incoming students are not familiar with the country they are going to. Usually, it is a country with a different religion, mentality and so on. Hence, looking for facilities outside the campus might be difficult, especially at the very beginning of studies.

What is more, this factor is closely related to financial support as well. Usually, the facilities provided on campus are cheaper than those supplied outside the campus; hence, for young people who do not have stable financial inflows, this aspect becomes extremely important. Another vital factor, according to the experts, is the accreditation of the programme and university. It is evident that international student comes to the university in order to receive new knowledge, gain new skills and, at the end, receive their diploma, which becomes impossible without accreditation. The weight of this factor is $10.2 \%$, with an absolute error of $\pm 2.9 \%$. The rest factors were considered as less important, and their weights are below $10 \%$. However, they remain vital as well and do have an influence on students' motivation to choose to study abroad, in our case in Europe.

\section{Conclusions}

The article analyses the factors that could have an impact on students from third countries to choose to study at European HEIs. On the basis of the scientific literature analysis, the following 10 factors were distinguished: ranking of the university, the reputation of the university, accreditation of the programme and university, facilities in the campus (latest technology used for teaching, library, cafeteria, etc.), educational qualification and work experience of teaching staff, accommodation facilities provided, scholarship opportunities, internship opportunities, programmes are taught in English and admission process is easy. In order to rank the factors and identify the most important ones, the expert evaluation method was chosen. The expert had to perform a pairwise comparison of the factors, and the results were processed using the AHP method. On the basis of the obtained results, the following factors are the most important for a student who wants to study at European HEI: programmes are taught in English, the existence of scholarship opportunities, provision of different facilities in the campus and accreditation of the study programme and university.

It is worth saying that the current research was aimed at weighting the educational factors only. However, there are more factors that affect young people's choice to study in Europe, such as financial factors, organisational factors and geographical factors. Consequently, in order to get a big picture, these factors have to be analysed in future studies.

\section{References}

Ahmad, S. Z., \& Hussain, M. (2017). An investigation of the factors determining student destination choice for higher education in the United Arab Emirates. Studies in Higher Education, 42(7), 1324-1343. https://doi.org/10.1080/03075079.2015.1099622

Blythe, J. (2008). Consumer behaviour. Thomson Learning.

Budur, T., Rashid, C. A., \& Poturak, M. (2018). Students Perceptions on University Selection, Decision Making Process: A Case Study in Kurdistan Region of Iraq. International Journal of Social Sciences \& Educational Studies, 5(1). https://doi.org/10.23918/ijsses.v5i1p133

Clarke, A., Fan, X., Webb, A., \& Zou, W. (2020). Becoming, belonging, and between: Unexpected outcomes and curricular implications for study abroad. Teaching and Teacher Education, 90, 103031. 
https://doi.org/10.1016/j.tate.2020.103031

Di Pietro, G. (2020). Changes in socioeconomic inequality in access to study abroad programs: A cross-country analysis. Research in Social Stratification and Mobility, 66, 100465. https://doi.org/10.1016/j.rssm.2019.100465

European Commission. (n.d.-a). European Credit Transfer and Accumulation System (ECTS). Education and Training. Retrieved 3 May 2020, from https://ec.europa.eu/education/resources-and-tools/european-credittransfer-and-accumulation-system-ects_en

European Commission. (n.d.-b). The Bologna Process and the European Higher Education Area. Education and Training. Retrieved 3 May 2020, from https://ec.europa.eu/education/policies/higher-education/bologna-processand-european-higher-education-area_en

European Commission. (2004). Council Directive 2004/114/EC of 13 December 2004 on the conditions of admission of third-country nationals for the purposes of studies, pupil exchange, unremunerated training or voluntary service. Official Journal of the European Union, L 375/12. https://eurlex.europa.eu/LexUriServ/LexUriServ.do?uri=OJ:L:2004:375:0012:0018:EN:PDF

European Commission. (2017). Higher education in Europe. Education and Training. https://ec.europa.eu/education/study-in-europe/planning-studies/european-higher-education_en

European Commission. (2018). Tertiary education statistics. https://bit.ly/2WnOAcw

Franek, J., \& Kresta, A. (2014). Judgment Scales and Consistency Measure in AHP. Procedia Economics and Finance, 12(March), 164-173. https://doi.org/10.1016/S2212-5671(14)00332-3

Gbollie, C., \& Gong, S. (2020). Emerging destination mobility. International Journal of Educational Management, 34(1), 18-34. https://doi.org/10.1108/IJEM-02-2019-0041

Guibourg, C. (2011). New fees prompt fears of cuts at Swedish universities. https://www.thelocal.se/20110822/35690

Hoyer, W. D., Pieters, R., \& MacInnis, D. J. (2012). Consumer Behavior (6th ed.). South-Western College Pub.

Kostin, L. V., \& [Костин, Л. В. ]. (2014). Использование метода анализа иерархий в процессе оценки потенциала клиентов рынка логистических услуг. Экономика и Управление, 3(39), 86-90.

Lee, C.-F. (2017). Exploring Motivations for Studying Abroad: A Case Study of Taiwan. Tourism Analysis, 22(4), 523-536. https://doi.org/10.3727/108354217X15023805452077

Lee, K. H. (2020). "I Post, therefore I Become \#cosmopolitan ": The materiality of online representations of study abroad in China. Population, Space and Place, 26(3). https://doi.org/10.1002/psp.2297

Leiškalne, A., Briede, I., \& Lopatinskis, S. (2018). Arrvalstu studentu piesaiste un noturēšana Latvijā. www.emn.lv María Cubillo, J., Sánchez, J., \& Cerviño, J. (2006). International students' decision-making process. International Journal of Educational Management, 20(2), 101-115. https://doi.org/10.1108/09513540610646091

Naito, T., \& Zhao, L. (2020). Capital accumulation through studying abroad and return migration. Economic Modelling, 87, 185-196. https://doi.org/10.1016/j.econmod.2019.07.018

Naito, T., Zhao, L., Pawar, S. K., Vispute, S., Islam, T., \& Chanda, R. (2020). International students' motivations for studying in Indian universities: Implications for value proposition and positioning strategies. Research in Comparative and International Education, 87, 185-196. https://doi.org/10.1177/1745499920910579

Patil, H., \& Bakkappa, B. (2012). The influence of culture on cosmetics consumer behavior. IOSR Journal of Business and Management, 3(4), 41-47. https://doi.org/10.9790/487x-0344147

Peighambari, K., Sattari, S., Kordestani, A., \& Oghazi, P. (2016). Consumer Behavior Research. SAGE Open, 6(2), 215824401664563. https://doi.org/10.1177/2158244016645638

Rika, N., Roze, J., \& Sennikova, I. (2016). Factors Affecting the Choice of Higher Education Institutions by Prospective Students in Latvia. CBU International Conference Proceedings, 4, $422-430$. https://doi.org/10.12955/cbup.v4.790

Saaty, T. L. (1993). Принятие решений: метод анализа иерархий. Радио и связь.

Saaty, Thomas L. (2012). Decision Making for Leaders: the analytic hierarchy process for decisions in a complex world (3rd ed.). RWS Publications.

Sojkin, B., Bartkowiak, P., \& Skuza, A. (2012). Determinants of higher education choices and student satisfaction: 
the case of Poland. Higher Education, 63(5), 565-581. https://doi.org/10.1007/s10734-011-9459-2

Spiers, S., Gundala, R. R., \& Singh, M. (2014). Culture and Consumer Behavior-A Study of Trinidad \&amp; Tobago and Jamaica. International Journal of Marketing Studies, 6(4). https://doi.org/10.5539/ijms.v6n4p92

Usunier, J. C., \& Lee, J. A. (2009). Marketing Across Cultures (5th ed.). Pearson Education Limited.

Wind, Y., \& Saaty, T. L. (1980). Marketing Applications of the Analytic Hierarchy Process. Management Science, 26(7), 641-658. https://doi.org/10.1287/mnsc.26.7.641

Wu, W., Chiang, C., \& Lin, C. (2008). Comparing the aggregation methods in the analytic hierarchy process when uniform distribution. WSEAS Transactions on Business and Economics, 5(3), 82-87.

Аксёнов, В. В., Блащук, М. Ю., \& Чернухин, Р. В. (2014). Применение метода анализа иерархий для выбора типа насоса энергосиловой установки геохода. Вестник Кузбасского Государственного Технического Университета, 3(103), 38-42.

\section{Appendixes}

Appendix 1: Consolidated and pairwise comparison matrices of experts

Consolidated

\begin{tabular}{|c|c|c|c|c|c|c|c|c|c|}
\hline 1 & 2 & 3 & 4 & 5 & 6 & 7 & 8 & 9 & 10 \\
\hline 1 & 0.535 & 0.525 & 0.305 & 0.654 & 0.542 & 0.315 & 0.516 & 0.204 & 0.607 \\
\hline 1.871 & & 0.706 & 0.281 & 0.946 & 0.694 & 0.282 & 0.724 & 0.223 & 0.626 \\
\hline 1.905 & 1.416 & & 1.408 & 1.488 & 1.435 & 0.561 & 0.917 & 0.604 & 1.501 \\
\hline 3.281 & 3.562 & 0.71 & & 1.615 & 1.391 & 0.736 & 1.804 & 0.344 & 1.145 \\
\hline 1.53 & 1.057 & 0.672 & 0.619 & & 1.13 & 0.569 & 1.007 & 0.271 & 0.985 \\
\hline 1.846 & 1.442 & 0.697 & 0.719 & 0.885 & & 0.488 & 2.044 & 0.209 & 0.81 \\
\hline 3.177 & 3.551 & 1.781 & 1.358 & 1.758 & 2.05 & & 3.753 & 0.719 & 1.811 \\
\hline 1.937 & 1.381 & 1.091 & 0.554 & 0.993 & 0.489 & 0.266 & & 0.369 & 0.923 \\
\hline 4.892 & 4.486 & 1.657 & 2.907 & 3.685 & 4.787 & 1.391 & 2.711 & & 2.615 \\
\hline 1.646 & 1.598 & 0.666 & 0.873 & 1.015 & 1.235 & 0.552 & 1.084 & 0.382 & \\
\hline
\end{tabular}

$E_{1}$

\begin{tabular}{|c|c|c|c|c|c|c|c|c|c|}
\hline 1 & $1 / 2$ & $1 / 5$ & $1 / 2$ & $1 / 4$ & $1 / 3$ & $1 / 2$ & $1 / 3$ & $1 / 2$ & 1 \\
\hline 2 & 1 & $1 / 3$ & $1 / 2$ & 3 & $1 / 4$ & $1 / 3$ & $1 / 2$ & 1 & 1 \\
\hline 5 & 3 & 1 & 3 & 6 & 4 & 4 & 3 & 3 & 6 \\
\hline 2 & 2 & $1 / 3$ & 1 & 3 & $1 / 3$ & $1 / 3$ & 2 & $1 / 4$ & 2 \\
\hline 4 & $1 / 3$ & $1 / 6$ & $1 / 3$ & 1 & $1 / 3$ & $1 / 3$ & $1 / 3$ & $1 / 4$ & $1 / 2$ \\
\hline 3 & 4 & $1 / 4$ & 3 & 3 & 1 & 3 & 2 & $1 / 2$ & 3 \\
\hline 2 & 3 & $1 / 4$ & 3 & 3 & $1 / 3$ & 1 & 2 & $1 / 2$ & 2 \\
\hline 3 & 2 & $1 / 3$ & $1 / 2$ & 3 & $1 / 2$ & $1 / 2$ & 1 & $1 / 4$ & 3 \\
\hline 2 & 1 & $1 / 3$ & 4 & 4 & 2 & 2 & 4 & 1 & 4 \\
\hline 1 & 1 & $1 / 6$ & $1 / 2$ & 2 & $1 / 3$ & $1 / 2$ & $1 / 3$ & $1 / 4$ & 1 \\
\hline
\end{tabular}

$\mathrm{E}_{3}$
$\mathrm{E}_{2}$

\begin{tabular}{|l|l|l|l|l|l|l|l|l|l|}
\multicolumn{1}{c}{2} & \multicolumn{1}{c}{3} & \multicolumn{1}{c}{5} & \multicolumn{1}{c}{7} & \multicolumn{1}{c}{8} & 9 & 10 \\
\hline 1 & $1 / 5$ & $1 / 9$ & $1 / 8$ & 1 & $1 / 9$ & $1 / 9$ & $1 / 9$ & $1 / 5$ & $1 / 9$ \\
\hline 5 & 1 & $1 / 7$ & $1 / 9$ & 2 & $1 / 3$ & $1 / 9$ & $1 / 9$ & $1 / 5$ & $1 / 9$ \\
\hline 9 & 7 & 1 & 5 & 1 & 5 & 1 & 1 & 5 & 5 \\
\hline 8 & 9 & $1 / 5$ & 1 & 9 & 1 & $1 / 5$ & $1 / 5$ & 8 & $1 / 9$ \\
\hline 1 & $1 / 2$ & 1 & $1 / 9$ & 1 & $1 / 5$ & $1 / 9$ & $1 / 9$ & $1 / 5$ & $1 / 9$ \\
\hline 9 & 3 & $1 / 5$ & 1 & 5 & 1 & $1 / 9$ & $1 / 9$ & 1 & $1 / 9$ \\
\hline 9 & 9 & 1 & 5 & 9 & 9 & 1 & 1 & 9 & 3 \\
\hline 9 & 9 & 1 & 5 & 9 & 9 & 1 & 1 & 9 & 3 \\
\hline 5 & 5 & $1 / 5$ & $1 / 8$ & 5 & 1 & $1 / 9$ & $1 / 9$ & 1 & $1 / 8$ \\
\hline 9 & 9 & $1 / 5$ & 9 & 9 & 9 & $1 / 3$ & $1 / 3$ & 8 & 1 \\
\hline
\end{tabular}

$\mathrm{E}_{4}$ 

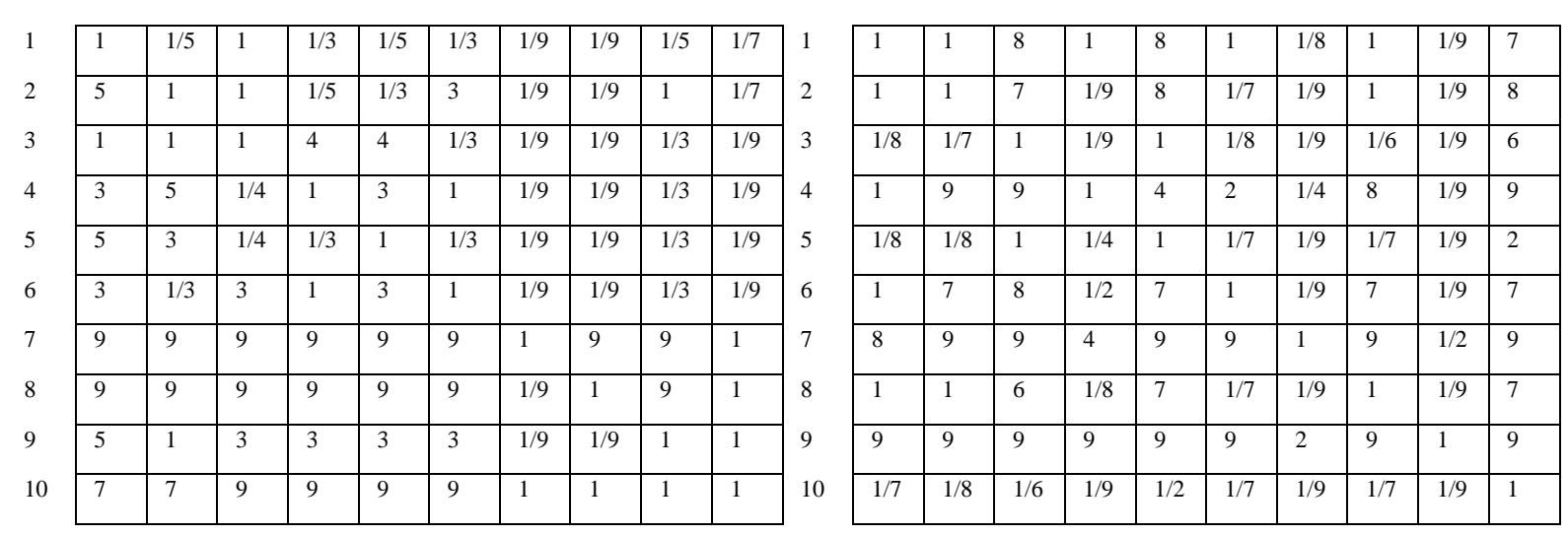

$\mathrm{E}_{5}$

$\mathrm{E}_{6}$
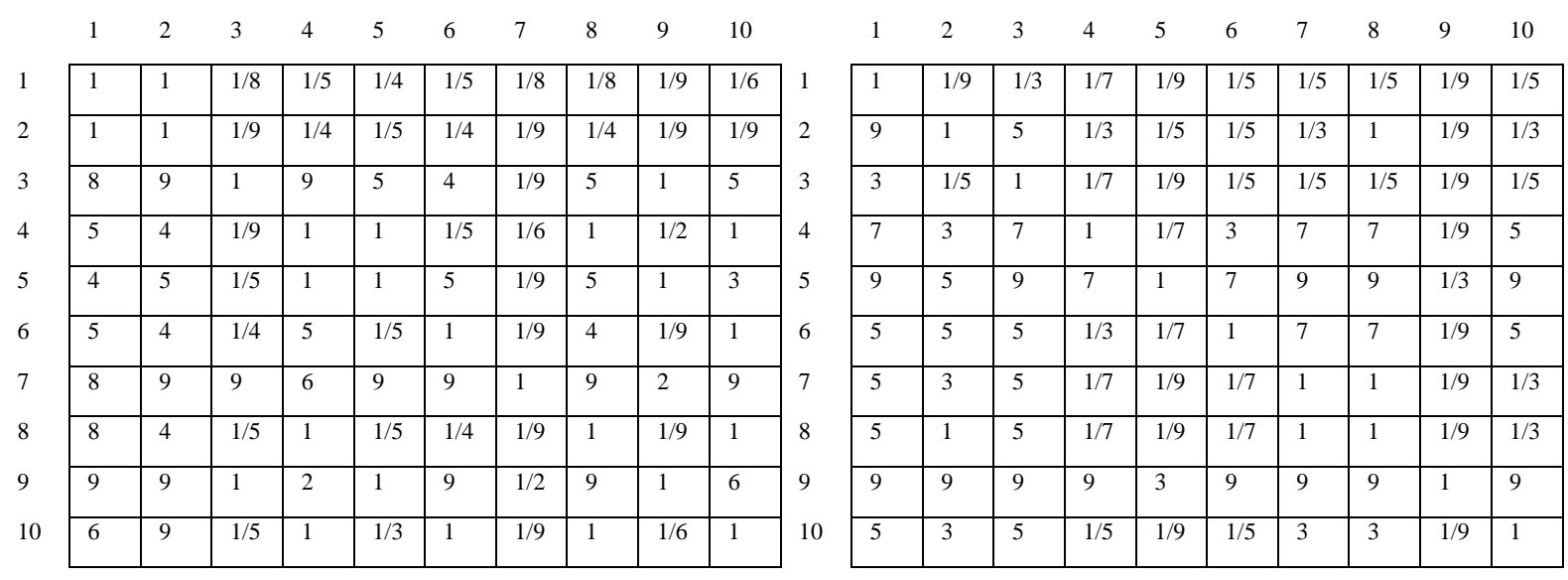

E7 E8

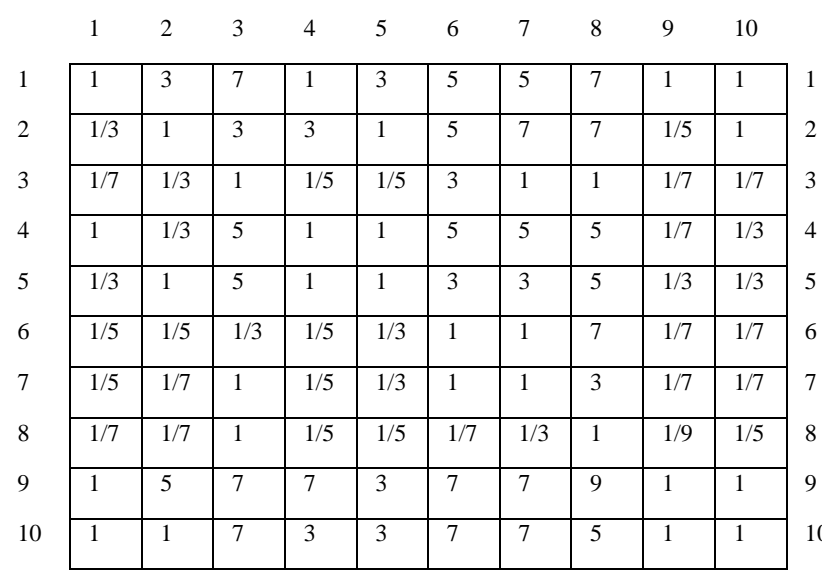

\begin{tabular}{l|l|l|l|l|l|l|l|l|l|}
1 & 2 & 3 & 4 & 5 & 6 & 7 & 8 & 9 & 10 \\
\hline 1 & 1 & $1 / 9$ & $1 / 8$ & 1 & 3 & 1 & 7 & $1 / 9$ & 5 \\
\hline 1 & 1 & $1 / 9$ & $1 / 8$ & 1 & 6 & $1 / 3$ & 7 & $1 / 9$ & 5 \\
\hline 9 & 9 & 1 & 9 & 9 & 9 & 9 & 9 & 2 & 9 \\
\hline 8 & 8 & $1 / 9$ & 1 & 1 & 7 & 8 & 9 & $1 / 3$ & 8 \\
\hline 1 & 1 & $1 / 9$ & 1 & 1 & 8 & 8 & 8 & $1 / 7$ & 8 \\
\hline $1 / 3$ & $1 / 6$ & $1 / 9$ & $1 / 7$ & $1 / 8$ & 1 & 1 & 9 & $1 / 9$ & 1 \\
\hline 1 & 3 & $1 / 9$ & $1 / 8$ & $1 / 8$ & 1 & 1 & 9 & $1 / 9$ & 5 \\
\hline $1 / 7$ & $1 / 7$ & $1 / 9$ & $1 / 9$ & $1 / 8$ & $1 / 9$ & $1 / 9$ & 1 & $1 / 9$ & $1 / 8$ \\
\hline 9 & 9 & $1 / 2$ & 3 & 7 & 9 & 9 & 9 & 1 & 9 \\
\hline $1 / 5$ & $1 / 5$ & $1 / 9$ & $1 / 8$ & $1 / 8$ & 1 & $1 / 5$ & 8 & $1 / 9$ & 1 \\
\hline
\end{tabular}

